\title{
Cahier « Guyanes »
}

\section{(2) OpenEdition}

1 Journals

Édition électronique

URL : https://journals.openedition.org/jsa/3843

DOI : 10.4000/jsa.3843

ISSN : 1957-7842

\section{Éditeur}

Société des américanistes

\section{Édition imprimée}

Date de publication : 1 janvier 2003

Pagination : 125-128

ISSN : 0037-9174

\section{Référence électronique}

"Cahier « Guyanes » », Journal de la Société des américanistes [En ligne], 89-1 | 2003, mis en ligne le 03 janvier 2008, consulté le 04 septembre 2022. URL : http://journals.openedition.org/jsa/3843 ; DOI : https://doi.org/10.4000/jsa.3843

Ce document a été généré automatiquement le 4 septembre 2022.

Tous droits réservés 


\section{Cahier « Guyanes »}

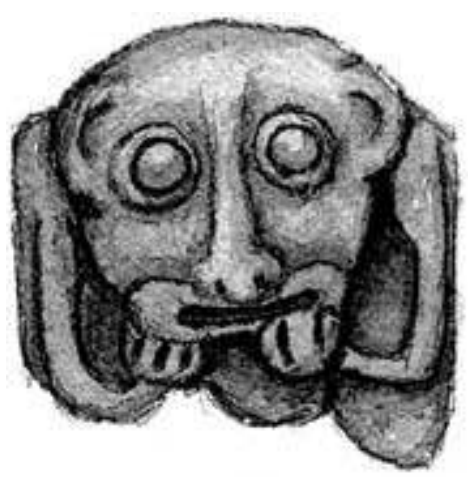

1 Un article et trois notes de recherche relatifs aux Guyanes ont été proposés simultanément pour publication au Journal de la Société des Américanistes. Ils témoignent d'un intérêt renouvelé pour l'étude archéologique et anthropologique de cette vaste région. À l'heure où la Guyane fait l'objet de multiples recherches, en biologie notamment, deux programmes ont été récemment mis en place dont les problématiques convergent sur plus d'un aspect. L'un est conduit par l'Équipe de recherche en ethnologie amérindienne (UPR 324 du CNRS) et le Núcleo de história indígena e do indigenismo de l'université de São Paulo (NHII-USP) : il s'intéresse aux réseaux sociaux dans les Guyanes orientales. L'autre, qui associe le laboratoire Archéologie des Amériques (UMR $8096 \mathrm{du}$ CNRS) et plusieurs institutions françaises et étrangères dans le cadre d'une Action collective de recherche financée par le ministère de la Culture et de la communication, concerne la préhistoire de la côte occidentale. Un point commun aux travaux ici rassemblés est de s'interroger sur la formation et la définition des ensembles ethniques ou culturels et sur leurs interactions dans l'histoire des Guyanes. Tant pour la préhistoire que pour les périodes historique et actuelle, ces interrogations sont au cœur des recherches engagées dans les deux programmes.

2 Casi simultáneamente se sometieron un artículo y tres notas de investigación para ser publicados en el Journal de la Société des Américanistes. Dan testimonio de la reactivación de los estudios arqueológicos y antropológicos en esta amplia región. Mientras se llevan a cabo en Guyana numerosas investigaciones, notable-mente biológicas, dos programas acaban de iniciarse, cuyas problemáticas convergen en más de un punto. El primero fue lanzado por el Équipe de recherche en ethnologie amérindienne (UPR 324 del CNRS) y el 
Núcleo de história indígena e do indigenismo de la universidad de São Paulo (NHII-USP) : está centrado en las redes sociales en la Guyanas orientales. El otro asocia el laboratorio Archéologie des Amériques (UMR 8096 del CNRS) y varias instituciones francesas y extranjeras, está financiado a través de una Action collective de recherche del ministerio francés de Cultura: se enfoca en las poblaciones pre-Contacto de la costa occidental. Los dos programas coinciden al interrogarse sobre la formación y definición de los grupos étnicos o culturales así como sobre sus interacciones a lo largo del tiempo. Tanto para la prehistoria como para los periodos históricos y actual estas preguntas son céntricas en los trabajos de ambos programas.

One article and three research notes on the Guyanas have been simultaneously presented to the Jounal de la Société des Américanistes for publication. They indicate a renewed interest in archeological and anthropological studies about this huge region. While a great variety of researches, above all in biology, are undertaken today in French Guiana, two new programs have been initiated, dealing with various issues. One is conducted jointly by the Équipe de recherche en ethnologie amérindienne (UPR 324 of the CNRS) and the Núcleo de história indígena e do indigenismo of the University of São Paulo (NHII-USP): this program is dealing with social network of Eastern Guiana. The second program associates the laboratory Archéologie des Amériques (UMR 8096 of the CNRS) and various French and foreign institutions within an Action collective de recherche, financed by the French Ministry for Culture and Communication. This second program deals with Western Guiana coastal prehistory. Both programs are linked through the joint interest in investigating the development and definition of ethnic and cultural groupings, as well as their interactions within the history of the Guyanas. Whether they are prehistorical, historical or contemporary, these investigations build the central interest of these two newly initiated research programs.

\section{INDEX}

Index géographique : Guyane, Guyanes

Thèmes : Archéologie, Ethnohistoire, Ethnologie 